\title{
Attitude of Junior Secondary School Students towards the Study of Science
}

\author{
Mensah, F. \\ Department of Primary Education \\ University of Cape Coast, Ghana
}

\begin{abstract}
This problem was studied in its proper perspective by analyzing the situation of girls' education in Science subjects, as it exists in Ghana with reference to J.S.S. pupils' attitude to Science. Using a stratified random sample of junior secondary school students from public and private schools, the study investigated the attitudes of junior secondary school students towards the study of science. Data were collected using survey instrument. The findings indicate that girls do not enjoy science as much as boys do.
\end{abstract}

Keywords: attitude, girls' education, gender, science and mathematics education,

\section{Introduction}

In Ghana, as in other African countries, mathematics and science are used as key subjects for admission to university and other forms of higher education. Due to lack of adequate instructional resources and equipment, poor teacher preparation and remuneration, and uninspired curricula, neither boys nor girls perform well in science and mathematics subjects at both primary and secondary school level (Female Education in Mathematics and Science in Africa [FEMSA], 1995). However, on average, girl's performance is far worst than that of boys. Some of the reasons attributable to this position of girls are; the girls' irregular school attendance due to house hold chores, teachers' low expectation of girls' performance, textbooks that stereotype girls as submissive and unintelligent, and rote learning which separates science learning from informal learning in the local environment (Science, Technology and Mathematics Education [STME] clinic for girls, 1995). Some researchers (Matyas, 1987) argue that elementary students of both sexes like science, and hope to study science. Starting from grade nine onwards, boys express slightly more positive science attitudes and greater interest in studying science and choosing a science career. Individual, national, and international studies have also confirmed the notion that girls have less confidence in their science abilities, and are less likely to participate in extracurricular activities (Stake, 1984).

The problem can be seen in the attention being given to it at both international and local levels. A number of international fora have been held to address the problem of gender stereotyping in the field of Science and technology. Between 1976 and 1980, the United Nations Educational and Cultural Organization (UNESCO), organized four international meetings aimed at improving access of female to technical and vocational education and training. Some are

1. International congress on the situation of women in technical and vocational Education (Bonn, 1980)

2. International Seminar on the Opening up to women of Vocational Training and Jobs Traditionally Occupied by men (Frankfurt, 1980) 
3. The International Seminar on Women, Education, Training and Employment in Developing Countries (Tokyo, 1980).

Not only do fewer women enter science and engineering fields, but there is increasing data suggesting that the science experience they have while growing up are distinctly different from those of their male counterparts. Within primary classrooms, males receive more praise, direct questions and behavioral warnings (Becker, 1982; Sikes, 1972). Male students are also asked more often to assist with demonstrations and experiment (Jones \& Wheatley, 1989). Curran (1980) observed that because girls perform poorly in science, teachers and parents tend to stream them into non-science and non-technical subjects and careers with the result that girls fail to acquire knowledge and skills that are important even for work that women normally do in health care, food cropping, environmental management and energy conservation.

Studies have documented the gender differences in involvement with the science content areas. Women who enter science fields tend to enter the biological sciences and males tend to enter the physical sciences and engineering. Many females regard the physical sciences as masculine and find the biological sciences more "girl friendly" (Fox, 1981; Hoyenga and Hoyenga, 1979; Kahle and Lakes, 1983). It is on this note that Easlea (1986) suggests that

the practice of physics is associated with a masculine ability to manipulate and control inanimate matter rather than a feminine ability to empathize, communicate and care. As a consequence, the discipline of physics may come to be embraced by many schoolgirls as one of the sciences furtherest removed from a stereotypically feminine realm of relating empathically and caringly to other human beings ....

Biology ... with its concern for living things appears more of value and emotion which women are expected to inhabit. Choosing the biological science as opposed to the physical science thus involves girls in fewer contradictions, and they receive more encouragement and support in their choice. (p.135-136)

In 1987, Ghana initiated new educational reforms, which now predisposes both boys and girls to wider choices in life. The new national curriculum requires both boys and girls, irrespective of their sexes, to study all stipulated subjects at the basic educational level. The educational reforms therefore take into consideration mainstreaming of women in education and does not discriminate at the basic level, thus helping to create equal opportunities for boys and girls. Also, at the basic educational level a great deal of emphasis is placed on acquisition of skills and knowledge in pre-vocational, pre-technical and basic sciences. However, science and technology related school subjects are areas where students' enrolments have been the least and performance has been poor. Female participation and performance have also been the poorest especially at higher levels. There had been reported cases of good performances of girls in science at Junior Secondary School level and the enrolments of girls in science at secondary school level had gone up from $11.6 \%$ to $23.0 \%$ in 1995; that is, more than doubled within a decade (MOE, 1999). Indications are that the new educational reforms are going to predispose students, particularly girls to the scientific enterprise.

It is however a well-known fact that given the option to choose subject to study in school, boys would normally choose subjects, which are considered masculine, whilst girls would choose subjects considered feminine. This tradition has existed in many educational institutions the world over, especially in institutions of higher learning. In general one finds more boys studying Physics, Mathematics or Mechanics and Technical subjects such as Woodwork and Blockwork. On the other hand, more girls are found studying Biology or social subjects like languages, secretarial subjects, humanities or vocational subjects like Cookery and Needlework (Whyte, 1984). 


\section{Review of Literature}

Studies directed at gender issues in science and technology are well documented. These studies have revealed misconceptions and stereotyped attitudes as being the major factor contributing to the negative attitudes of the society in general and also on the part of girls themselves. The literature continues to show that gender inequality in achievement, attitude and interest in science, technology and mathematics (STM) remains a contentious issue (Atwater, 1994; Baker, \& Leary, 1995; Jones \& Young, 1995) and requires solution to enable an equitable basis for effective curriculum and instruction in these subjects to be developed. Several sources of differential achievement and participation in STM include individual variables, cognitive abilities, attitudinal variables, home and family variables, and educational and school variables (Kahle \& Meece, 1994).

Studies conducted by Taiwo and Molobe (1994) indicated that both teachers and students identified the hard-core science subjects with the boys. They felt that these subjects are irrelevant to girls' future occupation. From the early stage children are socialized according to their gender roles through toys (Taiwo and Molobe, 1994) and cultural games (GaregaeGarekwe, 1994). For instance, in childhood experience girls pretend to be mothers and cook for their "children" and "husbands", whereas boys pretend to be husbands, build houses and drive cars.

\section{Purpose of the Study}

The purpose of this study was to

(i) find out the attitudes of junior secondary school students towards the study of science.

(ii) find out whether differences in attitudes exist among boys and girls towards the study of science.

\section{Methodology}

The study utilized cross-sectional survey designed to determine the attitudes of Junior Secondary School (JSS) students toward science. The target population was all Junior Secondary School (JSS) students in the Cape Coast Municipality of Central Region. The participants were 320 ( 150 boys and 170 girls) JSS 3 students from eight randomly selected Junior Secondary Schools in Cape Coast Municipality of Central Region of Ghana. These schools consisted of four public schools and four private schools. In the four public schools, there were 85 boys and 92 girls, giving a total of 177 students. In the four private schools, there were 65 boys and 78 girls giving a total of 143 students.

A survey instrument adapted from Mathematics Attitude Scale, developed by FennemaSherman (1986), was adapted to determine JSS 3 students' responses to 16 items. This questionnaire was referred to as Student Attitude Scale (SAS). The survey has four subscales: a) Pupils' Perception of each Other [PPO], b) Enjoyment of Science [EOS], c) Confidence about Science [CAS], and d) Perception of Teachers' Attitudes [PTA].

Each subscale indicated a construct based on which students' attitudes toward science were measured. Each of the subscales had four items. The students' attitudes toward science were ascertained by asking them to rate each statement in the survey (questionnaire) in terms of agreement or disagreement. Some of the statements in the survey were positive and some were negative. For positive statements, "Agree" was scored 3 points, "Uncertain", 2 points, and "Disagree" 1 point. For negative statements, the scoring was reversed. For each subscale, the maximum score for each participant was 12 and the minimum score was 4 . For content validity, the instrument was given to a panel of experts. After changes had been made, the Student Attitude Scale (SAS) instrument was piloted on forty-two JSS 3 students in one JSS school in Cape coast. This school did not form part of the sample. For the four subscales the alpha co-efficients were $0.81,0.74,0.70$, and 0.86 for PPO, EOS, CAS, and PTA respectively. The overall alpha value for the SAS instrument was 0.83 . 
Data for the study were collected between October 20, 2003 and October 31, 2003. The questionnaire was distributed to the students in each of the selected JSS 3 classrooms in the mornings, between 8:30 and 9:00. The purpose of the study was explained to the students and explanations were given as how to respond to the items. The completed instruments were collected that same morning.

\section{Results}

Independent means t-test was used to analyze the data collected on each construct. The results are presented in Table 1 .

Table 1 Independent means t-test results between JSS boys and girls on the constructs of PPO, EOS, CAS, and PTA

\begin{tabular}{|c|c|c|c|c|c|c|}
\hline Construct & $\begin{array}{c}\text { Sex of } \\
\text { Student }\end{array}$ & Number & Mean & SD & $\mathbf{t}$ & p value \\
\hline \multirow{2}{*}{ Perception of Each Other } & Male & 150 & 8.39 & 1.03 & \multirow{2}{*}{0.60} & \multirow{2}{*}{.512} \\
\hline & Female & 170 & 7.81 & 0.90 & & \\
\hline \multirow{2}{*}{ Confidence About Science } & Male & 150 & 9.94 & 1.14 & \multirow{2}{*}{1.62} & \multirow{2}{*}{.152} \\
\hline & Female & 170 & 8.24 & 0.95 & & \\
\hline \multirow{2}{*}{ Enjoyment of Science } & Male & 150 & 10.48 & 1.28 & \multirow{2}{*}{$2.73 *$} & \multirow{2}{*}{.004} \\
\hline & Female & 170 & 7.64 & 1.03 & & \\
\hline \multirow{2}{*}{ Teachers' Attitude } & Male & 150 & 10.38 & 1.19 & \multirow{2}{*}{$2.64 *$} & \multirow{2}{*}{.000} \\
\hline & Female & 170 & 7.70 & 0.83 & & \\
\hline
\end{tabular}

Table 1 shows significant difference between male and female JSS students' enjoyment of science and their perceptions of science teachers' attitude toward them. JSS male students (M $=10.48, \mathrm{SD}=1.28)$ enjoy studying science more than JSS female students $(\mathrm{M}=7.64, \mathrm{SD}=$ 1.0). Also, JSS male students $(M=10.38, S D=1.19)$ have a stronger perception than JSS female students $(M=7.70, S D=0.83)$ that science teachers' attitude toward students and science learning is more positive toward the male students and less positive toward the female students. However, no significant difference existed between male and female students on the construct of students' perception of each other $\mathrm{t}(320)=.60, \mathrm{p}>.05$, and students' confidence about science $\mathrm{t}(320)=1.62, \mathrm{p}>.05$.

\section{Findings and Discussion}

The finding of the study indicated that both male and female perceive science as belonging to both sexes. This finding is inconsistent with findings of Sadli (1989) that female students do not consider science as female domain. With respect to students' confidence about science learning, the findings suggested that both male and female students have confidence about science learning. This finding is also in sharp contrast to that of Sadli (1989) that girls lack confidence in their ability to excel in science. In the case of enjoyment of science, the findings revealed that girls don't like science as much as boys. This means that girls are more likely to spend less time studying the subject and consequently, less likely to perform as well as boys. Therefore, apart from the effect on performance, the fact that girls enjoy science less than boys is itself a failure. With regard to teachers' attitude toward them the findings indicated that teachers' attitude toward boys to be more positive than it is toward girls. This finding strongly agrees with that of Shephardson and Pizzini (1992) that teachers' have gender biased perception of girls' scientific ability. 


\section{Implications for Pupils, Teachers and Educational Leaders}

The findings of the study have implications for pupils, teachers and educational leaders. Girls may be unaware of their contribution to their lack of interest in science. Also, they may not be aware of the factors within their schools, classrooms, home and the larger society which are hindrance to their learning of science. Boys may not be aware of their contribution to hindering the science learning of girls. Therefore, if successful women scientists are asked to speak about their education, work and other related issues to both boys and girls, girls would be inspired to emulate them and boys would be supportive of girls' academic efforts in science.

Teachers may be unaware that their negative attitude toward girls in science learning may be the major contributory factor to girls' lack of enjoyment of science and not that the girls are afraid of science. If teachers are counseled they may begin to realize their fault and correct the erroneous impression that science is the preserve of boys. In so doing both boys and girls may be helped to enjoying science learning.

At the school level, three factors are particularly important influences of teacher and student performance: teacher knowledge and skills, teacher motivation, and the situation or context in which teachers work (Rowan, 1996). There is mounting evidence that teacher knowledge and skills may be the single most important determinant of variations in student achievement (Darling-Hammond, 1998; Wright, Horn and Sanders, 1997). Teacher knowledge and skills determine the ability of teachers to be effective in designing and delivering instruction. They are directly affected by teacher policies and management practices, most importantly preservice training and licensure requirement (Darling-Hammond, 1998). In combination with these "gatekeeper" policies, human resource policies, such as recruitment, compensation, evaluation, and professional development also have an important impact on teacher quality. Therefore, it is the responsibility of educational leaders and policy makers to institute and implement policies that will enhance teacher quality that in turn will influence student performance in all subject areas, especially in science, taking into consideration those factors that militate against science learning in Junior Secondary Schools.

\section{Recommendations}

The attitude of the pupils, as revealed above, shows that no matter how good interventions that might be proposed to address the problem of girls and science education in Ghana, they will be unlikely to succeed with isolated efforts by individuals. It is therefore suggested that

1. A wider sensitization of teachers, at least in the Departments of Science and Basic Education, in the post-secondary training colleges and in the teacher education universities, to the case of the difficulties girls have in learning science be organized.

2. Workshops should be organized for science teachers already in the field. During the workshops, the teachers must be required to reflect on their classroom practice. This is to get teachers to be part of an action to remedy the problems.

3. There is the need to ask women scientist to speak about their education, work, and other related issues to both boys and girls and not to girls alone as was being done at STME clinics.

4. If pupil involvement is extended to being researchers rather than only subjects of research, they may awakened to a number of issues, which might help improve their beliefs, attitudes and practices with respect to science beliefs. 
Attitude of Junior Secondary School Students towards the Study of Science

Mensah, F.

\section{References}

Atwater, M. M. (1994). Research on cultural diversity in the classroom. In D. L. Gabel (Ed.). Handbook of Research on Science Teaching and Learning. New York: Macmillan Publishing Company. (558-578).

Baker, D. \& Leary, R. (1995). Letting girls speak out about science. Journal of Research in Science Teaching, 32(1), 3-27.

Becker, J. R. (1982). Differential treatment of females and males in mathematics classes. Journal for Research in Mathematics Education, 12(1), 40-

Curran, L (1980). Science education: Did she drop out or was she pushed In L. Birke (Ed), Alice through the microscope. London: Virago. (pp.22-41)

Darling-Hammond, L. (1998). Teacher quality and student achievement: A review of state policy evidence. Stanford: Stanford University.

Easlea, B. (1986). The masculine image of science with special reference to physics: How much does gender really matter? In J. Harding, (Ed.), Perspective on Gender and science. Philadelphia: Palmen Press.

Fox, L. (1981). The problem of women and mathematics. NY: Ford Foundation.

Garegae-Garekwe, K. G. (1994). The use of cultural games in mathematics teaching: The study of teachers in Botswana. M.Ed Dissertation. University of Alberta, Edmonton.

Hoyenga, K.B. \& Hoyenga, K.T. (1979). The question of sex differences. Boston: Little Brown and Co., $235-261$.

Jones, J., \& Young, D. (1995). Perceptions and relevance of mathematics and science: An Australian study. Research in Science Education, 25(1), 3-18.

Jones, M. G., \& Wheatley, J. (1989). Gender influences in classroom displays and studentteacher behaviour. Science Education, 73(5), 525-545.

Kahle, J. B. \& Lakes, M. K. (1983). The Myth of equality in science classrooms. Journal of Research in Science Teaching, 20(2), 131-140.

Kahle, J. B., \& Meeece, J. (1994). Research on gender issues in the classroom. In D. L. Gabel (Ed.). Handbook of research on science teaching and learning. New York: Macmillan Publishing Company. (pp. 542-557).

Matyas, M. (1987). Keeping undergraduate women in science and engineering: Contributing factors and recommendations for action. GASAT 4, Ann Arbor, Michigan: GASAT.

MOE - Ghana Ministry of Education - (1999) National Education Forum Report, Accra: Ghana Ministry of Education

Rowan, B. (1996). Standards and incentives for instructional reform. In S. H. Fuhrman, \& J. O' Dag (Eds.), Reward and reform: Creating educational incentives that work. San Fransisco: Jossey-Bass. (pp. 195-225).

Sadli, S. (1989). Women and studies in science and technology: Supporting and Hindering and Hindering factors. Workshop on women n science and technology, August 21-22, Ambon.

Sikes, J. N. (1972). Differential behaviour of male and female teachers with male and female students. Dissertation Abstracts International, 217 A (University microfilms No. 721967).

Stake, J. (1984). Educational and career confidence and motivation among female and male undergraduates. American Educational Research Journal, 21(1), 565-578. 
Taiwo, A. A., \& Molobe, E. N. (1994). Gender dimensions of the perceptions of subject and career choices of students: A case of Botswana Senior Secondary Schools. Southern Africa Journal of Mathematics and Science Education, 1(1), 31-48.

Whyte, J. (1984). Observing sex stereotypes and interactions in the school lab and workshop. Educational Review, 36(1), 75-86.

Wright, S. P., Horn, S. P., \& Sanders, W. L. (1997). Teacher and classroom context effects on student achievement: Implications for teacher evaluation. Journal of Personnel Evaluation in Education, 11, 57-67. 